Kumawula, Vol. 3, No.2, Agustus 2020, Hal 197 - 203

DOI: https://doi.org/10.24198/kumawula.v3i2.26267

ISSN 2620-844X (online)

Tersedia online di http://jurnal.unpad.ac.id/kumawula/index

\title{
PENINGKATAN PENJUALAN DANDANG MENGGUNAKAN METODE VIRAL MARKETING DI DESA CILEUNYI KULON
}

\author{
Dianne Amor Kusuma \\ Departemen Matematika FMIPA Universitas Padjadjaran \\ amor@unpad.ac.id
}

\begin{abstract}
ABSTRAK
KKN Kewirausahaan di Desa Cileunyi Kulon ini secara umum bertujuan menanamkan jiwa nasionalisme, jiwa Pancasila, rasa tanggungjawab, kepemimpinan, kewirausahaan, serta meningkatkan empati dan kepedulian mahasiswa pada kehidupan masyarakat. Fokus kegiatan KKN ini adalah membantu masyarakat mengidentifikasi dan mengembangkan potensi usaha di Desa Cileunyi Kulon. Berdasarkan hasil survei, wawancara, dan pengamatan, ditemukan masalah, yaitu beberapa pengrajin dandang di Desa Cileunyi Kulon kesulitan memasarkan hasil usaha mereka. Alternatif metode pemasaran, yakni viral marketing diperkenalkan pada pelaku usaha dandang mengatasi masalah tersebut. Workshop mengenai metode viral marketing bagi pelaku usaha dandang di di Desa Cileunyi Kulon mendapat tanggapan yang sangat positif dari masyarakat Desa Cileunyi Kulon. Agar penerapan metode viral marketing ini dapat berkelanjutan, maka penyuluhan dan pelatihan pada masyarakat Desa Cileunyi Kulon secara rutin perlu dilakukan.
\end{abstract}

Kata kunci: Penjualan dandang, viral marketing, Cileunyi Kulon.

\section{IMPROVEMENT OF DANDANG SALES USING VIRAL MARKETING METHOD IN CILEUNYI KULON VILLAGE}

\begin{abstract}
The aims of entrepreneurship community service (KKN) activity in Cileunyi Kulon village in general is to instill the spirit of nationalism, the spirit of Pancasila, responsibility, leadership, entrepreneurship, as well as increasing students' empathy and their concern for community life. The focus of attention in this KKN activity is to help the community for identifying business potential in Cileunyi Kulon village and help to develop it. Based on the results of surveys, interviews, and observations, it was found that there were problems that some craftsmen of dandang in Cileunyi Kulon village difficult to market their products. It is necessary to apply an appropriate alternative marketing method, namely viral marketing, for solving the problem. The method used in the effort to apply viral marketing is by providing counseling and training to the people of Cileunyi Kulon village. The result of applying the viral marketing method in Cileunyi Kulon village was a very positive and enthusiastic response from the people of Cileunyi Kulon village. In order to the implementation of viral marketing method could be sustainable, it is advisable to hold counseling and training to the people of Cileunyi Kulon village regularly.
\end{abstract}

Keywords: Dandang sales, viral marketing, cileunyi kulon. 


\section{PENDAHULUAN}

Cileunyi Kulon merupakan salah satu desa yang terletak di wilayah Kecamatan Cileunyi Kabupaten Bandung yang berdiri sejak 1978. Luas Desa Cileunyi Kulon sekira 489,17 hektar, yang terbagi menjadi delapan dusun, 26 Rukun Warga (RW) dan 116 Rukun Tetangga (RT). Hingga akhir Desember 2019, jumlah penduduk Desa Cileunyi Kulon sekitar 22.442 jiwa. Sebagian besar penduduk Desa Cileunyi Kulon bekerja sebagai buruh tani, buruh harian lepas, karyawan perusahaan swasta, petani, pengusaha kecil dan menengah, serta pengrajin industri rumah tangga (Kusuma, 2019). Selain daripada itu, berdasarkan kondisi demografi, Desa Cileunyi Kulon memiliki banyak potensi yang berpeluang untuk dikembangkan (Buchari, et. al., 2019).

Berdasarkan hasil survei awal yang dilakukan pada 4 dan 5 Januari 2020, diperoleh data bahwa Desa Cileunyi Kulon memiliki beberapa potensi di bidang perekonomian, diantaranya: a) home industry pembuatan baju rajut di wilayah RW 06; b) industri senapan angin di wilayah RW 16 dan 17; c) industri alat rumah tangga (dandang) di wilayah RW 07, 08, 09 dan RW 10 serta 21; d) industry pengolahan makanan dari singkong di wilayah RW 03 dan 04; e) kerajinan tangan berbahan hanjeli di wilayah RW 12 dan 13; f) kerajinan daur ulang limbah kemasan di RW 10; g) produksi cipuk di wilayah RW 07; h) pemintalan benang di wilayah RW 07; i) kerajinan bunga akrilik di wilayah RW 17; j) produksi baja ringan di wilayah RW 11; k) kerajinan lukisan kanvas di wilayah RW 23; l) produksi aneka kue basah di wilayah RW 10; dan m) wisata alam cantigi di wilayah RW 03.

KKN Kewirausahaan ini dilaksanakan di Desa Cileunyi Kulon dengan cara melakukan berbagai kegiatan yang meliputi: 1) mengidentifikasi titik-titik lokasi usaha yang telah ada dan berjalan di Desa Cileunyi Kulon: 2) mengidentifikasi titik-titik lokasi yang berpeluang memiliki potensi untuk mengembangkan usaha: 3) berdiskusi dengan BUMDES di Cileunyi Kulon untuk mengetahui informasi jenis usaha yang sejauh ini telah dikelola dan yang belum dikelola, serta kendala BUMDES dalam mengelola usaha-usaha tersebut; 4) mengidentifikasi berbagai permasalahan ataupun kendala yang dihadapi masyarakat Desa Cileunyi Kulon dalam menjalankan serta mengembangkan usahanya: 5) memberikan solusi dari berbagai permasalahan ataupun kendala yang dihadapi masyarakat Desa Cileunyi Kulon dalam menjalankan dan mengembangkan usahanya; 6) mengadakan workshop tentang kewirausahaan bagi masyarakat Desa Cileunyi Kulon; dan 7) membuat web untuk 
mempromosikan beragam usaha yang ada di Desa Cileunyi Kulon agar dapat lebih dikenal masyarakat luas.

Hasil survei dan wawancara yang dilakukan selama kegiatan KKN Kewirausahaan pada 9 Januari hingga 12 Februari 2020, memperlihatkan bahwa permasalahan yang dihadapi masyarakat Desa Cileunyi Kulon adalah kesulitan dalam memasarkan hasil produksi mereka (terutama industri dandang yang paling banyak terdapat di Desa Cileunyi Kulon). Selain itu, para pelaku usaha pembuat dandang di Desa Cileunyi Kulon masih menerapkan teknik pemasaran tradisional, sehingga berdampak pada angka penjualan. Saat ini teknologi informasi berkembang sangat pesat dan telah diaplikasikan hampir di semua bidang, seperti: bidang pendidikan, kesehatan, ekonomi dan perdagangan, politik, sosial, kebudayaan, dan lain sebagainya. Di dalam bidang ekonomi dan perdagangan, teknologi informasi diaplikasikan sebagai salah satu upaya untuk memperkenalkan, mempromosikan, dan memasarkan beragam produk yang dihasilkan. Salah satu dari metode pemasaran yang menggunakan teknologi informasi adalah viral marketing. Kraus, et., al. (2009) menyatakan bahwa viral marketing adalah metode penyebaran pesan atau rumor mengenai suatu produk melalui komunikasi yang jujur dan sukarela yang dilakukan oleh pelanggan dengan tujuan untuk memperoleh pelanggan baru. Viral marketing memiliki banyak manfaat diantaranya: a) jangkauan pemasaran yang lebih luas; b) meminimalisir biaya operasional; c) pencarian dan pendistribusian informasi menjadi lebih mudah; d) mendukung layanan pelanggan tanpa ada batasan geografi dan waktu; e) biaya sistem pengontrolnya murah; dan f) membuat brand image yang lebih baik (Chaffey dan Dave, 2000). Berdasarkan uraian tersebut dan latar belakang masalah, maka penulis tertarik untuk menerapkan metode viral marketing dalam upaya meningkatkan penjualan dandang di Desa Cileunyi Kulon.

\section{Gambar 1. Industri Pembuat Dandang di Desa Cileunyi Kulon}




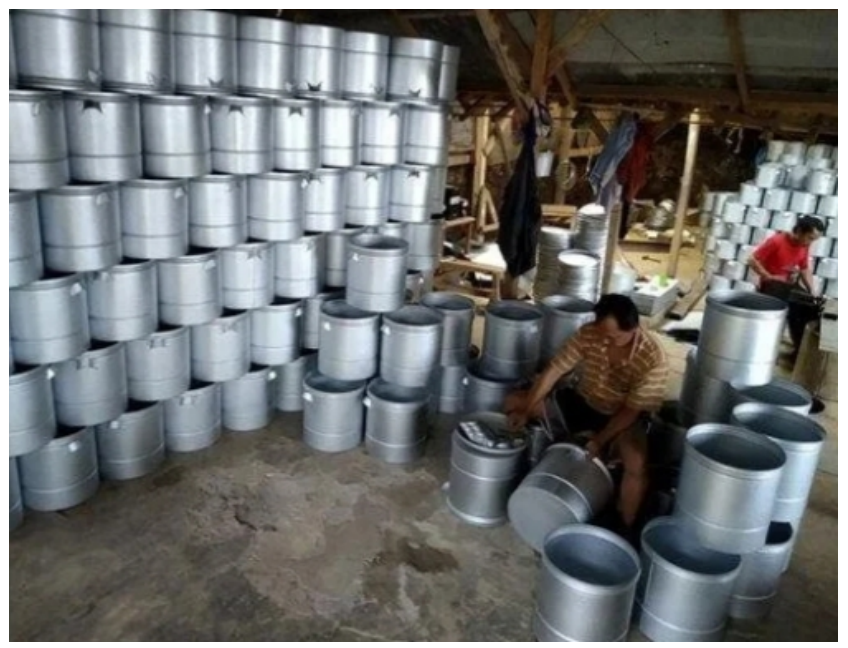

Sumber: http://jabar.tribunnews.com

\section{METODE}

Pelaksanaan kegiatan KKN Kewirausahaan di Desa Cileunyi Kulon dalam upaya meningkatkan penjualan dandang, menggunakan metode survei dan wawancara pada masyarakat Desa Cileunyi Kulon, serta memberikan workshop mengenai kewirausahaan, terutama mengenai penerapan metode pemasaran viral marketing bagi masyarakat. Metode yang diterapkan dalam kegiatan workshop adalah metode ekspositori (ceramah dan tanyajawab). Sasaran kegiatan KKN ini adalah seluruh masyarakat Desa Cileunyi Kulon, Instrumen yang digunakan dalam kegiatan ini adalah angket yang disebarkan pada masyarakat serta materi workshop.

Pelaksanaan kegiatan KKN Kewirausahaan ini terdiri atas tiga tahap, meliputi: tahap persiapan, pelaksanaan, dan evaluasi. Tahap persiapan terdiri atas: i) survei awal ; ii) penyusunan jadwal kegiatan; dan iii) penyusunan program kegiatan. Tahap pelaksanaan terdiri atas: a) wawancara dan survei lanjutan; b) identifikasi titik-titik lokasi industri pembuat dandang yang sudah ada; c) identifikasi permasalahan dan kendala yang dihadapi para pelaku industri-industri pembuat dandang; dan d) workshop tentang penerapan metode viral marketing sebagai upaya meningkatkan penjualan. Tahap evaluasi dilakukan untuk mengetahui peningkatan penjualan dandang di Desa Cileunyi Kulon setelah menerapkan metode viral marketing. Indikator keberhasilan tahap evaluasi dilihat dari peningkatan angka penjualan dandang di Desa Cileunyi Kulon.

\section{HASIL DAN PEMBAHASAN}

Tinggi rendahnya angka penjualan suatu produk dipengaruhi oleh beberapa faktor, salah 
satunya adalah metode pemasaran yang diterapkan. Hill dan Wright (2000), dalam penelitiannya menemukan bahwa banyak usaha kecil dan menengah (UKM) yang tidak melakukan perencanaan pemasaran secara formal dan cenderung menggunakan metode pemasaran yang sederhana, tidak tetap, serta berdasarkan intuisi tanpa struktur formal. Pendapat tersebut didukung oleh Barret dan Sexton (2006), yang mengemukakan bahwa UKM lebih fokus pada perencanaan keuangan daripada perencanaan pemasaran. Berdasarkan uraian tersebut dapat dikatakan bahwa beberapa pelaku usaha mikro, kecil, dan menengah (UMKM) tidak menerapkan (bahkan mengabaikan) rencana pemasaran. Hal itu disebabkan para pelaku usaha tidak mengerti dan merasa tidak perlu menerapkan rencana pemasaran. Kondisi demikian dihadapi juga oleh para pelaku usaha dandang di Desa Cileunyi Kulon (berdasarkan hasil wawancara dan survei). Mereka merasa kesulitan memasarkan produknya sehingga berdampak pada rendahnya angka penjualan.

Pemasaran terbagi atas dua jenis, yakni pemasaran entrepreneurial dan pemasaran tradisional. Pemasaran entrepreneurial adalah fungsi organisasi dan serangkaian proses menciptakan, mengkomunikasikan, serta menyampaikan nilai kepada pelanggan untuk mengelola hubungan dengan pelanggan dalam cara yang menguntungkan organisasi dan pihakpihak yang berkepentingan, serta berorientasi pada inovasi (Slamet, et. al., 2018), dan istilah ini mulai muncul pada tahun 1982. Pemasaran tradisional lebih berorientasi pada pelanggan. Kelebihan pemasaran entrepreneurial dibandingkan dengan pemasarn tradisional terletak pada aspek promosi yang dilakukan. Salah satunya adalah viral marketing. Viral marketing merupakan cara memasarkan suatu produk dengan menggunakan media internet, seperti email, twitter, facebook, youtube, dan instagram. Berdasarkan latar belakang masalah yang telah dipaparkan sebelumnya, kegiatan KKN Kewirausahaan ini akan memperkenalkan pada masyarakat, metode viral marketing sebagai alternatif solusi dari permasalahan yang dihadapi oleh pelaku industri pembuatan dandang di Desa Cileunyi Kulon.

Metode viral marketing merupakan teknik pemasaran yang membuat orang menyampaikan pesan pemasaran kepada orang lain secara sukarela (Kotler, 2009). Sukarela dalam arti ketika seseorang mengakses internet melalui e-mail, twitter, facebook, instagram, youtube, dan media sosial lainnya, kemudian secara spontan turut membagikan informasi yang dibaca ataupun yang ditonton kepada orang lain. Cara ini secara tidak langsung turut menyebarluaskan informasi tersebut kepada orang lain. Proses penyebaran informasi seperti ini sangat efektif dan berdampak positif (Bernhardt, et. al., 2012). 
Penerapan metode viral marketing yang dilakukan di Desa Cileunyi Kulon dilakukan melalui beberapa tahapan kegiatan yang meliputi: 1) minggu pertama, mengadakan wawancara dan survei terhadap industri-industri pembuat dandang yang ada di Desa Cileunyi Kulon; 2) minggu kedua dan ketiga, mengumpulkan bahan seperti foto-foto dan video mengenai kualitas dandang buatan Desa Cileunyi Kulon; dan 3) minggu keempat, mengadakan workshop kepada masyarakat Desa Cileunyi Kulon (diutamakan yang terlibat dalam industri pembuat dandang) mengenai penerapan metode viral marketing dalam upaya meningkatkan penjualan dandang di Desa Cileunyi Kulon.

Penerapan metode viral marketing pada industri-industri pembuat dandang di Desa Cileunyi Kulon bertujuan agar: i) angka penjualan dapat ditingkatkan; ii) dandang hasil produksi Desa Cileunyi Kulon dapat dikenal luas tidak hanya di Indonesia, bahkan dapat merambah hingga ke luar negeri; dan iii) para pelaku usaha pembuat dandang di Desa Cileunyi Kulon khususnya dan masyarakat Desa Cileunyi Kulon umumnya lebih “melek” teknologi. Kegiatan KKN ini disambut dengan antusias dan mendapat tanggapan yang sangat baik dari masyarakat. Hal ini ditunjukkan dengan ketertarikan mereka untuk belajar menggunakan internet sebagai media untuk menginformasikan serta mempromosikan produk-produk yang mereka hasilkan.

\section{SIMPULAN}

Masalah yang dihadapi para pelaku usaha pembuat dandang di Desa Cileunyi Kulon adalah kesulitan memasarkan produk mereka ke wilayah yang lebih luas dan sejauh ini mereka masih menerapkan teknik pemasaran tradisional, sehingga berdampak pada angka penjualan. Inti kegiatan KKN Kewirausahaan yang dilaksanakan di Desa Cileunyi Kulon ini adalah memperkenalkan metode viral marketing untuk membantu industri-industri pembuat dandang dalam upaya meningkatkan penjualan. Hasil kegiatan KKN ini telah berhasil membantu masyarakat Desa Cileunyi Kulon pada umumnya dan para pelaku usaha industri pembuat dandang di Desa Cileunyi Kulon khususnya, untuk memperkenalkan produknya secara lebih luas, dalam hal jangkauan wilayah pemasarannya, sehingga penjualan dandang pun dapat ditingkatkan. Agar penerapan viral marketing berkelanjutan, sebaiknya diberikan workshop secara rutin dilakukan bagi masyarakat Desa Cileunyi Kulon, terutama untuk memperkaya materi mengenai updating (pembaharuan) metode-metode pemasaran. Cara ini memungkinkan para pelaku usaha di Desa Cileunyi Kulon (tidak hanya industri pembuat dandang) untuk meningkatkan pengetahuan serta wawasan kewirausahaan mereka. 


\section{UCAPAN TERIMA KASIH}

Paper ini adalah hasil Pengabdian Kepada Masyarakat pada kegiatan KKN Kewirausahaan, yang terselenggara berkat kerjasama Universitas Padjadjaran dan Direktorat Jendral Pembelajaran dan Kemahasiswaan Kemenristekdikti tahun 2020. Ucapan terima kasih disampaikan kepada Rektor Universitas Padjadjaran, Dirjen Belmawa Kemenristekdikti, serta tim mahasiswa KKN Kewirausahaan Desa Cileunyi Kulon, yakni Adi Satrio, Atikah Khairunnisa, Syaiful Bahri, Marisa Amalia, Alfi Fadilah Alfidru, Putri Monika, Shania Azzahra, Maria Kristanti, Fajar Ismi Chaniago, Ilham Najib Hidayat, Tasya Azizah, Elsa Gayuh Citra Ningrum, Syarifah Naurah, Adivian Nur Zhafari, Aliya Nurfarikha, Bayu Prasetya, Prajna Paramita, Irene Retno, Sekar Widyaningrum, dan Dwi Yuri Arista, juga Camat Cileunyi, Kepala Desa dan Sekretaris Desa Cileunyi Kulon, serta seluruh masyarakat Desa Cileunyi Kulon.

\section{DAFTAR PUSTAKA}

Barret, P. \& Sexton, M. (2006). Innovation in Small, Project-Based Construction Firms. British Journal of Management, 17(4): 331-346.

Bernhardt, J. M., Mays, D., \& Hall, A. K. (2012). Social Marketing at the Right Place and Right

Time with New Media. Journal of Social Marketing, 2(2): 130-137.

Buchari, R. A., Darmawan, I., \& Zakaria, S. (2019). Pengembangan Potensi Kewirausahaan di Desa Cikeruh melalui Program “Cikeruhpreneur” dan Produk Unggulan “Pa Engsit”. Kumawula: Jurnal Pengabdian kepada Masyarakat Unpad, 2(3): 270-280.

Chaffey \& Dave. (2000). Internet Marketing. Pearson Education Limited, England.

Hill, J. \& Wright, L. T. (2000). Defining the Scope of Entrepreneurial Marketing: A Qualitative

Approach. Journal of Enterprising Culture, 8(1): 23-46.

Kotler, Philip, Kevin, \& Keller, L. (2009). Manajemen Pemasaran Jilid Satu. Erlangga, Jakarta.

Kraus, S., Harms, R., Fink \& Fink, M. (2009). Entrepreneurial Marketing: Moving beyond 
Marketing in New Ventures. International Journal of Entrepreneurship and Innovation Management, Special Issue.

Kusuma, D. A. (2019). Pemanfaatan Limbah Plastik untuk Pembuatan Paving Block di Desa Cileunyi Kulon. Kumawula: Jurnal Pengabdian kepada Masyarakat Unpad, 2(3): 211217.

Slamet, F., Tunjungsari, H. K., \& Le, M. (2018). Dasar-Dasar Kewirausahaan: Teori dan Praktik. Penerbit Indeks, Jakarta. 